\title{
HUBUNGAN ANTARA DUKUNGAN SOSIAL TEMAN SEBAYA DAN DISIPLIN KULIAH DENGAN MINAT MENGIKUTI KULIAH PADA MAHASISWA PROGRAM STUDI MANAJEMEN PRODUKSI PEMBERITAAN SEKOLAH TINGGI MULTI MEDIA YOGYAKARTA
}

\author{
Siti Sarifah ${ }^{1}$, Triana Noor Edwina ${ }^{2}$ \\ ${ }^{12}$ Universitas Mercu Buana Yogyakarta \\ 1'siti_sarifah78@yahoo.com, ${ }^{2}$ winasoeharto@gmail.com
}

\begin{abstract}
Abstrak
Penelitian ini bertujuan: (1) untuk mengetahui hubungan antara dukungan sosial teman sebaya dengan minat mahasiswa mengikuti kuliah di Program Studi Manajemen Produksi Pemberitaan, Sekolah Tinggi Multi Media Yogyakarta (2) untuk mengetahui hubungan antara disiplin kuliah dengan minat mahasiswa mengikuti kuliah di Program Studi Manajemen Produksi Pemberitaan, Sekolah Tinggi Multi Media Yogyakarta; dan (3) untuk mengetahui hubungan antara dukungan sosial teman sebaya dan disiplin kuliah dengan minat mahasiswa untuk mengikuti kuliah di Program Studi Manajemen Produksi Pemberitaan, Sekolah Tinggi Multi Media Yogyakarta. Populasi dalam penelitian ini adalah mahasiswa Program Studi Manajemen Produksi Pemberitaan, Sekolah Tinggi Multi Media Yogyakarta tahun 2012 dan 2013. Sampel penelitian ditentukan dengan menggunakan metode cluster sampling dan jumlah sampel adalah 97 mahasiswa. Dalam penelitian ini, instrumen pengukuran yang digunakan adalah dukungan sosial sebaya, disiplin kuliah, dan skala minat mahasiswa dalam mengikuti kuliah. Teknik analisis data menggunakan analisis korelasi product moment dan analisis regresi berganda. Hasil penelitian menunjukkan bahwa: (1) ada hubungan positif antara dukungan sosial sebaya dengan minat mahasiswa pada mengikuti kuliah di Program Studi Manajemen Produksi Pemberitaan, Sekolah Tinggi Multi Media Yogyakarta; (2) ada hubungan positif antara kuliah disiplin dengan mahasiswa pada kuliah berikut di Program Studi Manajemen Produksi Pemberitaan, Sekolah Tinggi Multi Media Yogyakarta; dan (3) ada hubungan antara dukungan sosial teman sebaya dan disiplin kuliah dengan minat mahasiswa untuk mengikuti kuliah di Program Studi Manajemen Produksi Pemberitaan, Sekolah Tinggi Multi Media Yogyakarta.
\end{abstract}

Kata kunci: dukungan sosial sebaya, disiplin kuliah, dan minat mahasiswa untuk mengikuti kuliah

\section{THE RELATIONSHIP BETWEEN PEER SOCIAL SUPPORT AND LECTURE DISCIPLINE WITH THE INTEREST ON FOLLOWING LECTURE IN STUDENTS OF MANAJEMEN PRODUKSI PEMBERITAAN PROGRAM STUDY, SEKOLAH TINGGI MULTI MEDIA YOGYAKARTA}

\author{
Siti Sarifah $^{1}$, Triana Noor Edwina Dewayani Soeharto ${ }^{2}$ \\ ${ }^{12}$ Universitas Mercu Buana Yogyakarta \\ 1'siti_sarifah78@yahoo.com, ${ }^{2}$ winasoeharto@gmail.com
}

\begin{abstract}
This research aims: (1) to find out the relationship between peer social support with the student's interest on following lecture in Manajemen Produksi Pemberitaan Study Program, Sekolah Tinggi Multi Media Yogyakarta (2) to find out the relationship between lecture discipline with the student's interest on following lecture in Manajemen Produksi Pemberitaan Study Program, Sekolah Tinggi Multi Media Yogyakarta; and (3) to find out the relationship between both of peer social support and lecture discipline with the student's interest on following lecture in Manajemen Produksi Pemberitaan Study Program, Sekolah Tinggi Multi Media Yogyakarta. The population in this study was the students of Manajemen Produksi Pemberitaan Study Program, Sekolah Tinggi Multi Media Yogyakarta class of 2012 and 2013. The research sample was determined by using cluster sampling method and the number of samples is 97 students. In this study, the measurement instrument used were peer social support, lecture discipline, and the scale of student's interest on following the lecture. The
\end{abstract}


data analysis technique used product moment correlation analysis and multiple regression analysis. The results showed that: (1) there was a positive relationship between peer social support with the student's interest on following lecture in Manajemen Produksi Pemberitaan Study Program, Sekolah Tinggi Multi Media Yogyakarta; (2) there was a positive relationship between disciplinary lecture with the student's on following lecture in Manajemen Produksi Pemberitaan Study Program, Sekolah Tinggi Multi Media Yogyakarta; and (3) there was a relationship between both of peer social support and lecture discipline with student's interest on following lecture in Manajemen Produksi Pemberitaan Study Program, Sekolah Tinggi Multi Media Yogyakarta.

Keywords: peer social support, lecture discipline, and student's interest on following the lecture

\section{PENDAHULUAN}

Pendidikan secara formal dan informal memegang peranan penting dalam menciptakan sumber daya manusia yang berkualitas. Menciptakan sumber daya manusia yang handal tidak terlepas dari peran aktif atau perhatian dari lingkungan dan kesadaran dari diri generasi itu sendiri untuk mau meningkatkan kemampuan atau intelektualitas dan wawasannya di segala bidang. Perguruan tinggi sebagai lembaga pendidikan formal dan basis perbaikan dan peningkatan kualitas pendidikan di Indonesia memiliki peran strategis untuk melakukan berbagai langkah konkrit dalam upaya menciptakan SDM Indonesia yang berkualitas dan memiliki daya saing yang tinggi (Hamalik, 2007).

Upaya menciptakan sumber daya manusia Indonesia tersebut melalui berbagai jenjang pendidikan yang dilaluinya. Salah satunya dapat dilakukan dalam jenjang perkuliahan. Mahasiswa memiliki tanggung jawab yang utama dalam pendidikan yaitu menyelesaikan jenjang perkuliahannya. Mahasiswa dalam melaksanakan kegiatan selaras dengan minat, bakat, kemampuan, motivasi, inisiatif, dan gairah untuk berprestasi lebih baik dengan berpegang teguh pada tujuan pendidikan serta memperhatikan keadaan lingkungan. Guna mencapai tujuan untuk mengikuti kuliah, mahasiswa membutuhkan dorongan dari dalam yang berupa minat mengikuti kuliah.

Di dalam kegiatan kuliah, minat mempunyai peranan yang penting. Bila seorang mahasiswa tidak memiliki minat dan perhatian yang besar terhadap objek yang dipelajari maka sulit diharapkan mahasiswa tersebut akan tekun dan memperoleh hasil yang baik dari belajarnya. Sebaliknya, apabila mahasiswa tersebut belajar dengan minat dan perhatian besar terhadap objek yang dipelajari, maka hasil yang diperoleh lebih baik. Seperti yang diungkapkan oleh Efendi dan Praja (1993) bahwa belajar dengan minat akan lebih baik daripada belajar tanpa minat. Begitu pula dengan kuliah, kuliah dengan minat akan lebih baik daripada kuliah tanpa minat.

Dari hasil observasi yang peneliti lakukan di Sekolah Tinggi Multi Media Yogyakarta pada tanggal 11 Februari 2013 terhadap mahasiswa semester I-VII yang berjumlah 206 mahasiswa terdapat 120 mahasiswa memiliki minat mengikuti kuliah yang rendah, yang ditunjukkan dengan sikap acuh ketika dosen memberikan materi kuliah, mahasiswa belajar ketika mau ujian, ketika dosen mengajar asyik bermain handphone/kirim sms, mahasiswa tidak 
pernah membahas materi kuliah ketika selesai kuliah apalagi mendiskusikan dengan teman, tidak pernah mencari referensi lain selain yang dianjurkan dosen, sulit berkonsentrasi dalam mengikuti kuliah, ada yang tidur ketika kuliah berlangsung, banyak yang tidak mengumpulkan tugas dari dosen, mahasiswa malas mengerjakan tugas dari dosen, tidak memperhatikan dengan sungguh-sungguh, tidak mencatat apa yang dijelaskan dosen, ngobrol dengan temannya, keluar-masuk kelas dengan alasan ke kamar mandi dan sebagainya bahkan diketahui pula di antara mahasiswa ada yang jarang masuk kuliah.

Selain melakukan observasi, peneliti juga melakukan wawancara pada tanggal 17 Februari 2014 dengan 20 mahasiswa. Berdasarkan hasil wawancara tersebut, mahasiswa menyatakan adanya ketidaksenangan mahasiswa pada mata kuliah tertentu, sehingga menyebabkan ketidaktertarikan terhadap kegiatan kuliah dan kurangnya perhatian pada mata kuliah tertentu di saat perkuliahan berlangsung sehingga kurangnya minat untuk mengikuti kuliah mahasiswa tersebut. Kondisi demikian tidak dapat dibiarkan saja, perlu dilakukan pembenahan dan dicarikan solusi terbaik agar minat untuk mengikuti kuliah mahasiswa dapat meningkat.

Minat yang tinggi cenderung menghasilkan prestasi yang tinggi, sebaliknya minat yang kurang akan menghasilkan prestasi yang rendah (Dalyono, 1997). Hal itu sejalan dengan yang dikatakan oleh Nasution (1998) bahwa pelajaran akan berjalan lancar apabila ada minat, apabila siswa tidak ada minat maka mereka akan malas belajar, sehingga gagal dalam belajar. Penelitian tentang minat untuk mengikuti kuliah ini penting, karena minat merupakan salah satu faktor untuk meraih sukses dalam belajar (Khairani, 2013).

Ada beberapa faktor yang mempengaruhi minat dalam mengikuti kuliah menurut Slameto dalam Khairani (2013), diantaranya faktor intern yang meliputi faktor biologis, faktor psikologi, cita-cita, kebutuhan, kepuasan, bakat, kebiasaan, yang mengambil faktor disiplin kuliah dan faktor eksternal meliputi faktor kelengkapan sarana dan prasarana, pergaulan dengan orang tua, masyarakat, latar belakang sosial budaya, yang mengambil faktor dukungan sosial teman sebaya. Namun didalam penelitian ini hanya mengambil faktor dukungan sosial teman sebaya dan disiplin kuliah, dengan alasan karena hampir sepertiga dari waktunya setiap hari dilewatkan mahasiswa di kampus, sehingga dimungkinkan factor dukungan sosial teman sebaya dan disiplin kuliah memberikan kontribusi pada minat untuk mengikuti kuliah mahasiswa.

Dukungan sosial adalah bantuan yang diterima individu dari orang lain atau kelompok di sekitarnya, dengan membuat penerima merasa nyaman, dicintai dan dihargai (Sarafino, 1994). Konsep operasional dari dukungan sosial adalah perceived support (dukungan yang dirasakan), yang memiliki dua elemen dasar diantaranya adalah persepsi bahwa ada sejumlah orang lain dimana seseorang dapat mengandalkannya saat dibutuhkan dan derajat kepuasan terhadap dukungan yang ada (Dimatteo, 2004).

Menurut Tarakanita (2001), dukungan sosial yang bersumber dari teman sebaya dapat 
membuat remaja memiliki kesempatan untuk melakukan berbagai hal yang belum pernah mereka lakukan serta belajar mengambil peran yang baru dalam kehidupannya. Remaja mampu menjalankan peran sosialnya di masyarakat apabila remaja tersebut telah berhasil membentuk identitas dirinya. Tarakanita (2001), mengatakan bahwa, teman sebaya selain merupakan sumber referensi bagi remaja mengenai berbagai macam hal, juga dapat memberikan kesempatan bagi remaja untuk mengambil peran dan tanggung jawab yang baru melalui pemberian dorongan (dukungan sosial).

Dukungan sosial teman sebaya yang digunakan dalam penelitian ini adalah teori Cowie dan Wallace (Kusumadewi, dkk, 2010) bahwa dukungan sosial teman sebaya adalah dukungan yang dirasakan seorang mahasiswa, yang dibangun dan bersumber dari teman sebaya, mereka secara spontan menawarkan bantuan kepada mahasiswa tersebut, dan hal tersebut dapat terjadi dimanapun dan di kelompok sebaya manapun, serta memberi dukungan di saat kawan lainnya dalam kesulitan.

Apabila dalam sebuah kelompok mahasiswa mereka memperoleh dukungan, emosional, dukungan penghargaan, dukungan instrumental, dukungan informatif dan dukungan jaringan sosial, maka akan berhubungan dengan minat mengikuti kuliah mahasiswa tersebut (Sarafino, 1998).

Kebersamaan mahasiswa dengan teman sebayanya dibutuhkan, dengan adanya teman yang membantu di bidang akademis mempunyai dampak positif yang bersifat langsung terhadap mahasiswa. Pendapat ini dikuatkan oleh Hurlock (1992) bahwa minat dipengaruhi oleh dukungan sosial di antaranya teman sekelas dan sikap teman sebayanya. Hal ini menimbulkan kebutuhan mahasiswa untuk menjadi lebih berminat dalam mengikuti kuliah.

Menurut Dennis, Phinney and Chuateco (2005), motivasi pribadi, motivasi karir, dukungan teman sebaya juga berpengaruh pada suksesnya mahasiswa dalam mengikuti kuliah. Selain itu, salah satu faktor internal yang menentukan minat mengikuti kuliah mahasiswa adalah faktor disiplin kuliah, Marcal (2001), mengatakan bahwa disiplin dapat tercermin dalam ketaatan dan kepatuhan mahasiswa terhadap peraturan perguruan tinggi yang berlaku. Bentuk disiplin kuliah tersebut meliputi ketertiban terhadap aturan (adanya ketaatan dan kepatuhan terhadap peraturan, tanggung jawab (berani menanggung resiko) dan penguasaan diri (tidak semua keinginan dapat terpenuhi), hal ini menurut Durkheim (1990) dan Abu (1989). Mahasiswa yang memiliki ketertiban terhadap aturan maka akan menimbulkan minat dalam mengikuti kuliah, dengan adanya tanggung jawab yang dimiliki, maka akan menimbulkan minat mengikuti kuliah dan dengan adanya penguasaan diri yang dimiliki mahasiswa akan timbul minat dalam mengikuti kuliah seorang mahasiswa di kampus.

Disiplin merupakan suatu keadaan tertib, taat dan bertanggung jawab menjalankan tugas sesuai dengan peraturan, tata tertib dengan sungguh-sungguh serta dengan rasa tanggung jawab yang tinggi. Menurut Slameto (2010), kaitannya dengan kegiatan belajar mengajar, seorang siswa yang sudah terbiasa disiplin akan 
mempergunakan waktu belajar dengan sebaikbaiknya, baik di rumah maupun di sekolah. Sikap disiplin yang dimilikinya akan membuat dirinya mampu untuk mengatur waktu yang akibatnya mahasiswa tersebut mampu mengikuti proses belajar mengajar dengan optimal dan termasuk didalamnya dapat meningkatkan minat mengikuti kuliah. Disiplin kuliah berkaitan erat dengan minat untuk mengikuti kuliah. Sekolah yang tertib dan teratur akan membangkitkan sikap dan perilaku disiplin siswa (Saefullah, 2012).

Menurut penjelasan diatas dapat disimpulkan bahwa dukungan sosial teman sebaya dan disiplin kuliah akan mempengaruhi minat mengikuti kuliah pada mahasiswa Program Studi Manajemen Produksi Pemberitaan Sekolah Tinggi Multi Media Yogyakarta, inilah yang kemudian membuat ketertarikan peneliti untuk meneliti kedua faktor internal dan eksternal minat mengikuti kuliah tersebut. Dukungan sosial teman sebaya merupakan salah satu aspek penting dalam meningkatkan minat mengikuti kuliah pada mahasiswa, karena dengan adanya dukungan sosial dari teman sebaya yang dirasakan dan disiplin kuliah yang dimiliki, meliputi ketertiban terhadap aturan, tanggung jawab dan penguasaan diri akan memberikan dampak yang positif kepada mahasiswa, dan minat mengikuti kuliah pada mahasiswa akan meningkat.

Berdasarkan tinjauan teoritis di atas maka peneliti mengajukan hipotesis sebagai berikut;

1. Ada hubungan positif antara dukungan sosial teman sebaya dengan minat mengikuti kuliah pada mahasiswa Program Studi Manajemen Produksi
Pemberitaan Sekolah Tinggi Multi Media Yogyakarta, semakin tinggi dukungan sosial teman sebaya, maka semakin tinggi minat mengikuti kuliah pada mahasiswa Manajemen Produksi Pemberitaan Sekolah Tinggi Multi Media Yogyakarta.

2. Ada hubungan positif antara disiplin kuliah dengan minat mengikuti kuliah pada mahasiswa Program Studi Manajemen Produksi Pemberitaan Sekolah Tinggi Multi Media Yogyakarta.

3. Ada hubungan antara dukungan sosial teman sebaya dan disiplin kuliah secara bersama-sama dengan minat mengikuti kuliah pada mahasiswa Program Studi Manajemen Produksi Pemberitaan Sekolah Tinggi Multi Media Yogyakarta.

\section{METODE}

Penelitian ini melibatkan 3 variabel sebagai berikut :

1. Dukungan Sosial Teman Sebaya.

Dukungan sosial teman sebaya adalah dukungan yang dirasakan, seorang mahasiswa dan bersumber dari teman sebaya. Dukungan sosial teman sebaya akan diungkap dengan skala dukungan sosial teman sebaya sesuai pendapat Sarafino (1998), yang meliputi: dukungan emosional, dukungan penghargaan, dukungan instrumental, dukungan informatif dan dukungan jaringan sosial.

2. Disiplin Kuliah 
Yang dimaksud disiplin kuliah adalah kesadaran, kesediaan dan kepatuhan seseorang untuk mentaati semua peraturan, keputusan atau perintah dan norma-norma sosial yang berlaku yang berlaku dalam kegiatan kuliah di lingkungan perguruan tinggi. Disiplin kuliah akan diungkap dengan skala disiplin kuliah. sesuai pendapat Durkheim (1990) dan Abu (1989) yaitu ketertiban terhadap aturan, tanggung jawab dan penguasaan diri.

\section{Minat Mengikuti Kuliah}

Minat mengikuti kuliah adalah gejala psikis sebagai kecenderungan seseorang untuk memperhatikan dan tertarik kepada perbuatan mengikuti kuliah dengan kemauan yang kuat yang disertai dengan rasa senang, sehingga memberikan kepuasan dalam mengikuti kuliah, dan tujuan yang diharapkan dalam kuliah dapat tercapai. Minat mengikuti kuliah akan diungkap dengan skala minat mengikuti kuliah sesuai dengan pendapat Khairani (2013) yaitu: perasaan senang, ketertarikan dan perhatian.

Skala Dukungan Sosial Teman Sebaya, Disiplin Kuliah dan Minat Mengikuti Kuliah pada mahasiswa diuji cobakan pada 41 mahasiswa Program Studi Manajemen Produksi Pemberitaan Semester VI di kampus Sekolah Tinggi Multi Media Yogyakarta pada hari Jumat tanggal 22 Juni 2014.

Hasil dari pengujian terhadap validitas dan reliabilitas skala dukungan sosial teman sebaya menghasilkan 21 aitem yang valid dari 30 aitem yang diuji cobakan. Koefisien validitas bergerak antara 0,225 sampai dengan 0, 725, sedangkan untuk pengujian reliabilitas menggunakan cronbach alpha, menunjukkan koefisien reliabilitas sebesar 0,881 . Hasil dari pengujian terhadap validitas dan reliabilitas pada skala disiplin kuliah menghasilkan 13 aitem yang valid dari 24 aitem yang diuji cobakan. Koefisien validitas bergerak antara 0,238 sampai dengan 0,447 , sedangkan untuk pengujian reliabilitas menggunakan cronbach alpha, menunjukkan koefisien reliabilitas sebesar 0,755. Hasil dari pengujian terhadap validitas dan reliabilitas pada skala minat mengikuti kuliah menghasilkan aitem valid sebanyak 29 aitem yang valid dari 44 aitem yang diuji cobakan. Koefisien validitas bergerak antara 0,207 sampai dengan 0,537 , sedangkan untuk pengujian reliabilitas menggunakan cronbach alpha menunjukkan koefisien reliabilitas sebesar 0,814 .

Penelitian ini merupakan penelitian Populasi, karakteristik subjek penelitian dalam penelitian ini adalah mahasiswa program studi Manajemen Produksi Pemberitaan Sekolah Tinggi Multi Media Yogyakarta semester II dan IV. Jumlah subjek dalam penelitian ini adalah 97 mahasiswa.

Pengujian hubungan antara satu variabel independen dengan satu dependen (dukungan social teman sebaya dengan minat mengikuti kuliah atau disiplin kuliah dengan minat mengikuti kuliah pada mahasiswa) dengan metode analisis korelasi product moment. Sedangkan pengujian hubungan dua variable independen secara bersama-sama dikorelasikan 
dengan variable dependen (hubungan antara dukungan sosial teman sebaya dan disiplin kuliah dengan minat mengikuti kuliah pada mahasiswa) dengan menggunakan metode analisis regresi.

\section{HASIL DAN PEMBAHASAN}

Berdasarkan hasil uji korelasi dapat diketahui bahwa variabel dukungan sosial teman sebaya mempunyai hubungan positif dan signifikan dengan minat mengikuti kuliah mahasiswa sehingga $\mathrm{p}<0,05$, ini menunjukkan bahwa hipotesis 1 terbukti. Besarnya nilai $r=$ 0,272 , apabila dikuadradkan $\left(\mathrm{r}^{2}\right)$ menjadi 0,073 .

Koefisien determinasi $\left(r^{2}\right)$ sebesar 0,073, mempunyai arti bahwa dukungan sosial teman sebaya memberikan sumbangan efektif terhadap minat mengikuti kuliah pada mahasiswa sebesar $7,3 \%$ sedangkan sisanya sebesar $92,7 \%$ dipengaruhi variabel lain.

Berdasarkan hasil analisis data tersebut di atas yang menyatakan ada hubungan positif antara dukungan sosial teman sebaya dengan minat mengikuti kuliah pada mahasiswa Program Studi Manajemen Produksi Pemberitaan Sekolah Tinggi Multi Media Yogyakarta dalam penelitian ini diterima, dengan demikian dapat diartikan bahwa semakin tinggi dukungan sosial teman sebaya, maka minat mengikuti kuliah pada mahasiswa akan cenderung tinggi, dan sebaliknya semakin rendah dukungan sosial teman sebaya maka minat mengikuti kuliah pada mahasiswa akan cenderung rendah.

Sesuai dengan penelitian Alhumaira (2012) bahwa ada pengaruh yang positif dan signifikan antara lingkungan teman sebaya dengan minat siswa memilih kompetensi keahlian administrasi perkantoran SMK N 1 Klaten.

Penelitian Azis (2012), menyebutkan bahwa terdapat pengaruh yang positif dan signifikan antara lingkungan teman sebaya dengan minat menjadi guru mahasiswa Program Studi Administrasi Perkantoran FIS UNY. Hasil penelitian ini menunjukkan bahwa lingkungan teman sebaya masih memberikan pengaruh terhadap minat mahasiswa, artinya bahwa keputusan seorang mahasiswa masih ada hubungannya dengan lingkungan teman sebayanya, disamping faktor yang lainnya.

Variabel disiplin kuliah mempunyai hubungan yang positif dan signifikan terhadap minat mengikuti kuliah pada mahasiswa dengan ( $\mathrm{p}<0,05)$. Hal tersebut menunjukkan bahwa hipotesis 2 terbukti. Besarnya nilai $r=0,441$, apabila dikuadradkan $\left(\mathrm{r}^{2}\right)$ menjadi 0,194. Koefisien determinasi $\left(r^{2}\right)$ sebesar 0,194, hal tersebut menunjukkan bahwa hipotesis 2 diterima. dan disiplin kuliah memberikan sumbangan efektif terhadap minat mengikuti kuliah pada mahasiswa sebesar 19,4 \% sedangkan sisanya sebesar $80,6 \%$ dipengaruhi variabel lain.

Jadi, hipotesis dua yang menyatakan ada hubungan antara disiplin kuliah dengan minat mengikuti kuliah pada mahasiswa Program Studi Manajemen Produksi Pemberitaan Sekolah Tinggi Multi Media Yogyakarta dalam penelitian ini diterima, artinya bahwa semakin tinggi disiplin kuliah, maka minat mengikuti kuliah pada mahasiswa akan cenderung tinggi, sebaliknya jika disiplin kuliah rendah maka 
minat mengikuti kuliah pada mahasiswapun akan cenderung rendah.

Hasil hipotesis dua sesuai dengan pendapat Hurlock (1992), minat dipengaruhi oleh dukungan sosial di antaranya teman sekelas dan sikap teman sebayanya. Hal ini menimbulkan kebutuhan mahasiswa untuk menjadi lebih giat belajar. Slameto (2003) mengungkapkan bahwa pergaulan teman sebaya juga berpengaruh terhadap minat.

Dari pembahasan tersebut dapat disimpulkan bahwa jika dukungan sosial teman sebaya yang dirasakan mahasiswa tinggi, maka minat mengikuti kuliah akan cenderung tinggi, dan sebaliknya jika dukungan sosial teman sebaya yang dirasakan mahasiswa rendah, maka minat mengikuti kuliah akan cenderung rendah. Hal tersebut sesuai dengan penelitian Rosyadi (2012) yang menyatakan bahwa ada pengaruh yang positif dan signifikan antara kedisiplinan dengan minat mengikuti kegiatan di sekolah.

Hipotesis 3 diuji dengan uji regresi, dari uji regresi diketahui besarnya nilai $\mathrm{F}$ sebesar 14.752 dan $\mathrm{p}=0,000(\mathrm{p}<0,05)$ dapat disimpulkan bahwa variabel dukungan sosial teman sebaya dan disiplin kuliah mempunyai hubungan secara bersama-sama dengan minat mengikuti kuliah pada mahasiswa. Ini menunjukkan bahwa hipotesis 3 diterima. Besarnya nilai $\mathrm{R}=0,489$ apabila dikuadratkan $\left(\mathrm{R}^{2}\right)$ menjadi 0,239. Koefisien determinasi $\left(\mathrm{R}^{2}\right)$ sebesar 0,239 artinya besarnya sumbangan efektif variabel dukungan sosial teman sebaya dan disiplin kuliah secara bersama-sama terhadap minat mengikuti kuliah pada mahasiswa sebesar 23,9\% sedangkan sisanya sebesar 76,1\% dipengaruhi oleh variabel lain yang tidak dimasukkan dalam penelitian ini.

Adapun faktor-faktor yang mempengaruhi minat mengikuti kuliah yang tidak dimasukkan dalam penelitian ini yakni terdiri dari faktor internal dan faktor eksternal (Slameto dalam Khairani, 2013). Faktor internal meliputi kebutuhan, cita-cita, bakat, kepuasan, dan faktor ekternal yang mempengaruhi minat mengikuti kuliah mahasiswa yakni kelengkapan sarana prasarana, pergaulan dengan orang tua, masyarakat.

Dari penelitian yang dilakukan diketahui pula bahwa dukungan sosial teman sebaya yang dirasakan mahasiswa Program Studi Manajemen Produksi Pemberitaan Sekolah Tinggi Multi Media termasuk dalam kategori sedang, hal tersebut didapat dari hasil persentase untuk kategori sedang sebanyak 99\%, dan dengan kategori rendah sebanyak $1 \%$. Hasil tersebut menunjukkan bahwa mahasiswa yang memiliki dukungan sosial teman sebaya cenderung pada klasifikasi sedang. Keadaan dilapangan menunjukkan bahwa mahasiswa memang mulai merasakan dukungan sosial teman sebaya dalam mengikuti kuliah, hal tersebut terlihat dari pengamatan peneliti mahasiswa mulai terlihat banyak kegiatan yang dilakukan bersama.

Dari penelitian yang dilakukan, diketahui pula bahwa disiplin kuliah yang dimiliki mahasiswa Program Studi Manajemen Produksi Pemberitaan Sekolah Tinggi Multi Media termasuk dalam kategori sedang, hal tersebut didapat dari hasil persentase sebanyak 3\% dalam kategori tinggi, untuk kategori sedang sebanyak $97 \%$, dan tidak ada siswa yang 
memiliki disiplin kuliah rendah. Keadaan dilapangan menunjukkan bahwa mahasiswa memang mulai memiliki disiplin dalam mengikuti kuliah, hal tersebut terlihat dari pengamatan peneliti mahasiswa mulai terlihat disiplin dalam mengikuti kuliah meskipun ada beberapa yang masih kelihatan bermain handphone ketika dosen mengajar, ada yang acuh ketika dosen menjelaskan, masuk ruang kuliah terlambat dan sebagainya.

Dari hasil penelitian yang dilakukan diketahui bahwa minat mengikuti kuliah mahasiswa Program Studi Manajemen Produksi Pemberitaan Sekolah Tinggi Multi Media Yogyakarta berada pada kategori sedang. Diketahui bahwa subjek yang memiliki minat mengikuti kuliah dengan klasifikasi tinggi sebanyak $1 \%$, untuk kategori sedang sebanyak $98 \%$, dan ada mahasiswa yang mempunyai minat mengikuti kuliah dalam kategori rendah sebanyak $1 \%$. Dari hasil klasifikasi skor minat mengikuti kuliah dan keadaan dilapangan, maka dapat disimpulkan bahwa minat mengikuti kuliah pada mahasiswa Program Studi Manajemen Produksi Pemberitaan Sekolah Tinggi Multi Media Yogyakarta berada pada kategori sedang.

Semua klasifikasi yang telah dijelaskan tersebut di atas dapat peneliti simpulkan bahwa mahasiswa Program Studi Manajemen Produksi Pemberitaan di Sekolah Tinggi Multi Media Yogyakarta merasakan dukungan social teman sebaya dalam kategori sedang, mahasiswa memiliki disiplin kuliah dalam kategori sedang dan minat mengikuti kuliah mahasiswa dalam kategori sedang.

\section{KESIMPULAN}

Berdasarkan hasil analisis korelasi Product Moment dan analisis regresi linier berganda dapat disimpulkan bahwa:

1. Ada hubungan positif antara dukungan sosial teman sebaya dengan minat mengikuti kuliah pada mahasiswa Program Studi Manajemen Produksi Pemberitaan Sekolah Tinggi Multi Media Yogyakarta, sehingga semakin tinggi dukungan sosial teman sebaya, maka akan mempengaruhi minat mengikuti kuliah pada mahasiswa, dan sebaliknya semakin rendah dukungan sosial teman sebaya maka akan mempengaruhi minat mengikuti kuliah pada mahasiswa.

2. Ada hubungan positif antara disiplin kuliah dengan minat mengikuti kuliah pada mahasiswa Program Studi Manajemen Produksi Pemberitaan Sekolah Tinggi Multi Media Yogyakarta, sehingga semakin tinggi disiplin kuliah mahasiswa, maka minat mengikuti kuliah pada mahasiswa akan cenderung tinggi, sebaliknya jika disiplin kuliah mahasiswa rendah maka minat mengikuti kuliah pada mahasiswapun akan cenderung rendah.

3. Ada hubungan antara dukungan sosial teman sebaya dan disiplin kuliah secara bersama-sama dengan minat mengikuti kuliah pada mahasiswa Program Studi Manajemen Produksi Pemberitaan Sekolah Tinggi Multi Media Yogyakarta, sehingga semakin tinggi dukungan sosial teman sebaya yang dirasakan mahasiswa dan mahasiswa memiliki disiplin kuliah tinggi, maka minat mengikuti kuliah pada 
mahasiswa semakin tinggi sebaliknya jika dukungan sosial teman sebaya yang dirasakan rendah dan mahasiswa memiliki disiplin kuliah yang rendah, maka minat mengikuti kuliah pada mahasiswa cenderung rendah.

\section{DAFTAR PUSTAKA}

Abu, R. (1989). Disiplin Murid SMTA di Lingkungan Pendidikan Formal pada Beberapa Propinsi di Indonesia. Jakarta: Balai Pustaka.

Alhumaira A.F. (2012). Pengaruh Lingkungan Keluarga dan Lingkungan Sebaya terhadap minat siswa memilih kompetensi keahlian administrasi perkantoran. Skripsi. Universitas Negeri. Yogyakarta.

Dalyono, (2007). Psikologi Pendidikan. Jakarta: Rineka Cipta.

Dennis, J.M. Phinney, J.S. \& Chuateco, L.I. The Role of Motivation, Parental Support, and Peer Support in the Academic Success of Ethnic Minority First Generation College Students. Journal of College Student Development, 46 (3), 223-226.

Dimatteo, M. R. (2004). "Social Support and Patient Adherence to Medical Treatment: a Meta Analysis". Health Psychology Journal, 23(2), 207-218.

Durkheim. E. (1990). Pendidikan Moral. Terjemahan: Lukas Ginting. Jakarta: PT Erlangga.

Effendi, U. \& Juhaya, S. P. (1993). Pengantar Psikologi. Bandung: Angkasa.

Hamalik, O. (2007). Kurikulum dan Pembelajaran. Jakarta: PT BumiAksara.

Khairani, M. (2013). Psikologi Belajar. Yogyakarta. Azwaja Pressindo.

Kusumadewi. S., Tuti H., \& Aditya N.P. (2010). Hubungan antara Dukungan Sosial Peer Group dan Control Diri dengan Kepatuhan terhadap Peraturan pada
Remaja di Pondok Islam Sukoharjo. Jurnal Ilmiah Psikologi Candra Jiwa, I(2), 1-10.

Nasution, S. (1984). Berbagai Pendekatan dalam Proses Belajar Mengajar. Jakarta: Bina Aksara.

Saefullah, U. (2012). Psikologi Perkembangan dan Pendidikan. Bandung: Pustaka Setia

Sarafino, E.P. (1998). Health Psychology: Biopsychosocial Interaction $\left(3^{\text {rd }}\right)$ New York: John Wiley \& Sons.Inc.

Slameto. (2010). Belajar dan Faktor-faktor Yang Mempengaruhinya. Jakarta: Rineka Cipta.

Tarakanita, I. (2001). Hubungan Status Identitas Etnik Dengan Konsep Diri Mahasiswa. Jurnal Psikologi, 7(01), 01-14. 